\title{
The Study of the Education and Management Strategy of Overseas Students in China under "The Belt and Road" Initiative
}

\author{
Yan $\mathrm{He}^{1, \mathrm{a}^{*}}$ \\ ${ }^{1}$ Qiqihar Medical University, Heilongjiang 161006,China \\ a839852891@qq.com \\ * the corresponding author
}

Keyword: Education and management strategy; Overseas students; "The Belt and Road" Initiative.

\begin{abstract}
With the "The Belt and Road" initiative, the new period of overall strategy of China's Open policies increasingly clear, which will further promote the comprehensive development of China and other countries along with the deepening cooperation. It has also brought new opportunities and challenges for the internationalization of China's higher education, especially the education of overseas students in China. But with the international students in China continues expanding, the scale of foreign student's education and management pressure increases. There is a huge difference between our university student's education and management and the requirement coming from "The Belt and Road" initiative. The present methods of education and management are still relatively backward, and there are many shortcomings. This article comprehensively and deeply analyzed the problems of education and management of foreign students under the background of "The Belt and Road "initiative and put forward the corresponding countermeasures.
\end{abstract}

\section{Introduction}

At present, it is important to carry out education reform in Colleges and Universities At the time, "The Belt and Road national strategy under the background of higher education should strive for the "The Belt and Road" along the country to cooperate, explore new higher education new space platform, and on this basis to adhere to the "The Belt and Road" principle, and assistance to higher education in developing countries. Therefore, intensify efforts to carry out the education and management of foreign students is the most important part of the reform of Higher Education. It is also important to further open to the outside world, promote cultural exchanges and economic cooperation means.

\section{Problems of Education and Management of Overseas Students in China under "The Belt and Road" Initiative}

Organization Structure of International Student Management. At present, our country school education management of students of the two grade management system of University and college, the school set up the College of international education, international cooperation department and other similar institutions, mainly responsible for the enrollment, students daily management, registration and other related services, jointly responsible for the teaching of the academic affairs office, Graduate School, College International Education and related professional college dormitory management, arranged by the school logistics department, the school security department is responsible for the safety and stability of the. This organization will bring two problems: one is the student management organization is neither school authorities and non two colleges, school level in an awkward position, has no affiliation with the relevant functional department and two colleges, the lack of unified organization and coordination of the educational management of students, management is loose and inefficient; two is for students there are many management problems, students learn to face the life of many departments, great inconvenience for them. "The Belt and Road" along the 65 China international students proportion change trend of table 1 . 
Table 1 "The Belt and Road" along the 65 China international students proportion change trend

\begin{tabular}{ccccc}
\hline Year & Educated student & Junior college student & Undergraduate & Graduate student \\
\hline 2014 & 53.7 & 1.4 & 74.7 & 23.7 \\
2015 & 53.8 & 1.6 & 72.5 & 25.6 \\
2016 & 53.4 & 2.0 & 71.5 & 26.4 \\
2017 & 56.0 & 2.1 & 68.7 & 29.0 \\
\hline
\end{tabular}

Table 2 "The Belt and Road" along the 65 China international students proportion change trend

\begin{tabular}{ccccc}
\hline Year & Non academic student & General Scholar & Senior Scholar & Short-term international \\
\hline 2014 & 46.1 & 59.0 & 0.3 & 40.3 \\
2015 & 46.0 & 58.7 & 0.2 & 40.7 \\
2016 & 46.4 & 59.0 & 0.4 & 40.4 \\
2017 & 43.8 & 57.0 & 0.6 & 42.2 \\
\hline
\end{tabular}

Team Building of Foreign Students' Management Staff. The overall quality of foreign students' educational management personnel is directly related to whether the training task of foreign students can be implemented to each student. The reform and innovation of higher education management concept, first is to improve the comprehensive quality of staff and management personnel, to train a group of high quality, ability, knowledge, business skills of students management, this to our country continue to promote the "Belt and Road Initiative" strategy has an important and far-reaching significance. The student management team in Colleges and universities in China are mainly in the following two aspects: one is the complicated structure and serious aging, mainly from the student management staff of college foreign department or college authorities deployed personnel, there are some rehiring retirees and external personnel, lack of professional knowledge, occupation identity and sense of belonging is not high. Two imports is not strict, sluggish exports, college students management personnel in the recruitment, only requires a master's degree or above, English level is higher, did not put forward candidates with education, management science, psychology and other disciplines background. After entering the job, the lack of corresponding vocational training, career promotion channel is not clear, the assessment system is imperfect.

Guidance of International Students' Cross-cultural Adaptation. Our colleges and universities establish the students' academic guidance center, mental health counseling center, funded management service center, employment guidance service center, logistics service center and other institutions in order to build a perfect service system for domestic students, give full range for the students during the learning of life service. However, the working scope of these services has not covered the group of overseas students, and the overseas students have come to China, and there is very little knowledge about Chinese social culture, laws and regulations, life knowledge, etc.. After entering the school, the school's historical background, campus life, the surrounding environment is also not familiar with. At the same time, foreign students in foreign countries to study, psychological pressure, more prone to psychological problems, the future career development, the lack of appropriate guidance. Therefore, the lack of cross-cultural adaptation guidance for foreign students in China is basically lacking.

\section{Education and Management Strategy of Overseas Students in China under "The Belt and Road" Initiative}

Improving the Management System of International Students. Establishing a standardized and effective student education management evaluation system is an inevitable choice for the internationalization of higher education Chinese, for our country to enhance the international image and expand the international influence of education, has important and far-reaching significance to attract more foreign students to study in china. 
Evaluate the work of educational management of students, we must first correct assessment work attitude, establish the correct values, to establish a fair, impartial and open, reasonable and effective evaluation system, evaluation process and design scheme, which makes the evaluation with strong credibility, and ultimately the formation of virtuous cycle assessment and sustainable development. Secondly, strengthen the evaluation of the organizational guarantee of education management in the students assessment of important content included in the special university school level assessment; education departments at all levels should regularly or irregularly to within the jurisdiction of the university to carry out the evaluation work of colleges and universities; improve the internal self assessment work, actively cooperate with the audit department in charge of education. The timely introduction of the third party evaluation mechanism, accept social supervision, the formation of three-in-one evaluation system government, universities and society.

Strengthening the Management of Team Construction of International Students. The quality image of foreign students' education management personnel not only represents the image of the school, but also represents the image of the country. The professionalization and specialization of the foreign student management team is the inevitable requirement of the internationalization of the university. To strengthen the management team construction of students, the first thing is to optimize the structure of management team, the International Institute of education positions and responsibilities, the relevant administrative departments and departments with the school management of students to form student management personnel as the main body, administrative departments at all levels and departments of management personnel for assistance, external personnel to supplement the study the management team. Second, strengthen business training, regular training, seminars and work salon, pay attention to foreign language, education, psychology and cultural communication ability training. Third, reasonable enhance the propaganda of national policies, and the establishment of appropriate funds to support the students management personnel to go abroad for further study, strengthen the work of assessment, smooth promotion channels, stimulate the enthusiasm and initiative of students management work. Finally, efforts should be made to introduce overseas talents with international backgrounds; encourage foreign tutors to actively participate in the management of international students; employ foreign experts in part-time form to promote the teaching of international students education management.

Strengthening Cultural Adaptation and Academic and Cultural Guidance. Paying attention to the cross-cultural adaptation of international students of various problems encountered in the process of University, the comprehensive reform of the colleges and universities in the process of the construction of the service system will be included in the overall planning of the students of the school, specifically from the following four aspects: first, according to the actual situation of students, to develop in line with the demand of talent training scheme in different countries and the establishment of academic areas, student support system, the implementation of the assimilation management, encourage students learning together with Chinese students to teaching, experiment and practice and other aspects, to promote scientific research cooperation and cultural integration, enhance the training quality of students. Second, pay attention to the mental health problems of international students, bring them into the school mental health crisis warning and mental health service system, provide psychological counseling for the students in need, and ensure the healthy growth of foreign students. Third, we need to improve the financial aid system for overseas students, and attract more excellent international students to study in China by improving the standards and scope of foreign students' scholarships and grants. The construction of China occupation development guidance system of students, strengthen employment and entrepreneurship education, to guide students to actively integrate into the "The Belt and Road "strategy, cultivate a large number of high-level professional and technical personnel as the" The Belt and Road" along the country.

Foreign students education is an important part of the national "soft power" construction, is an important part of higher education, is a national important support for the implementation of "one way" strategy. To strengthen the education and management of students is an important way to improve the level of higher education service "The Belt and Road construction. From the aspects of management system and mechanism, management team building, students cross cultural guidance, apartment management, community activities, management evaluation mechanism analysis of the current student education management problems, 
combined with the background of The Belt and Road "the implementation of the national strategy, by improving the student management system, strengthen the students the management team construction, strengthen the cultural adaptation and academic guidance, countermeasures and suggestions of strengthening the students association construction and perfect students evaluation mechanism etc.. The education of overseas students in China is in the process of rapid development, is facing many new situations and new situation, which requires the students education management must have innovation, change the traditional thinking, promote students development of education management, provide strong support to the implementation of "The Belt and Road" strategy.

\section{Acknowledgments}

This work was financially supported by the project of philosophy and social science in Qiqihar, Heilongiiang province. The name of this project is "The Study of the Education and Management Strategy of Overseas Students in China under 'The Belt and Road' Initiative" and the project number is QSX2016-31JL.

\section{References}

[1] Wang Huiyao, Sun Yuhong, Miao Lv. Enterprise internationalization Blue Book: Chinese enterprise globalization report (2015) [M]. Beijing: Social Sciences Literature Press, 2015: 118.

[2] Lin Jinhui, Liu Zhiping. Research on Sino foreign cooperative education in Higher Education [M]. Guangzhou: Guangdong higher education press, 2010: 4.

[3] Zhou Changen. Research on international exchange and cooperation of Higher Vocational Colleges in Fujian [D]. Fu Fujian Normal University, 2012.

[4] Lorig KR , Holman HR . Self - management education : history, definition, outcomes, and mechanisms[J]. Annual of Behavioral Medicine, 2003, 26 (1) :1-7.

[5] Du Pengcheng, Zhao Shuming. Drucker's classic management thought $[\mathrm{J}]$. Foreign economy and management Li, 2009,31 (11): 6.

[6] Zhang Hui, Xiao Nan. College students' self management method and its practice innovation [J]. Dalian University Journal of science and technology, 2014,35 (4): 15. 